\section{Biletska Y., Bilovska 0., Zaitseva A.}

\title{
DESIGN OF NEW FOOD FOR DIET PURPOSES ACCORDING TO CONSUMER PREFERENCES
}

В роботі приведені дослідження проектування нового м'ясного продукту дієтичного призначення у відповідності до споживчих переваг. Об'єктом дослідження були потенційні споживачі м'ясних продуктів. 210 осіб які приймали участь у експерименті були практично здорові, 390 осіб мали певні захворювання. А саме: 109 осіб із йод-дифічитними станами, 154 особи із захворюванням целіакія, 127 осіб із захворюванням иукрового діабету II типу. Предметом дослідження були їх споживчі переваги. Аналізуючи дані опитування встановлено, що усвідомлені вимоги споживачів до нового м'ясного продукту дієтичного призначення це - дієтичні властивості та звичні органолептичні показники, тривалий термін зберігання та невисока иіна готового виробу. Не усвідомлені вимогами це - натуральний склад, який збалансований залежно від дієтичного призначення, наявність безпечних функціональних інгредієнтів та відсутність негативного впливу на організм. Встановлено, що під час виробництва м'ясних виробів для хворих на целіакію потрібно повністю виключити із рецептур м'ясних продуктів пшеничне борошно, замінюючи його на безглютенові види борошна - соєве, нутове, що збагатить м'ясні вироби на незамінні амінокислоти. Така заміна доцільна і для осіб, які страждають на иукровий діабет, де кількість легкозасвоюваних вуглеводів повинна бути обмежена. Що стосується споживчих переваг осіб із йод-дефіцитними станами, то представники даного сегменту хочуть споживати м’ясні вироби, які є носіями органічних форм йоду та селену із зниженим вмістом повареної солі. Застосування QFD-методологї дозволить мінімізувати невідповідності між виробником м'ясного продукту та вимогами споживачів до цього продукту після його появи на ринку. А також забезпечити високу чінність та одночасно відносно низьку вартість продукту за рахунок зведення до мінімуму витрат на виправлення невідповідностей.

Ключові слова: споживчі властивості, м’ясний продукт, дієтичні продукт, будинок якості, QFD-методологія.

Received date: 18.09.2019

Accepted date: 21.10.2019

Published date: 30.12 .2019
Copyright (C) 2019, Biletska Y., Bilovska O., Zaitseva A. This is an open access article under the CC BY license (http://creativecommons.org/licenses/by/4.0)

\section{Introduction}

Today in the state the average life expectancy of citizens is 10-12 years lower than in the countries of the European Union [1, 2], while more than $50 \%$ of the population eats inadequately, unbalanced. This contributes to the development of nutritional and nutritional-dependent diseases [3]. The Cabinet of Ministers of Ukraine adopted the National Target Program «Health 2020: The Ukrainian Dimension», the concept of which is entrusted with the development of high-quality consumer goods that should have a healthimproving, dietary effect and satisfy the requirements of patients with certain diseases [4].

Meat products occupy second place in the list of products that are in demand among the population, yielding to bakery and dairy products [5].

The study of the characteristics of customers and the identification of their needs will allow to design a meat product that will be competitive in the market. That is, in terms of their consumer properties and economic indicators, to satisfy consumers, not inferior to, and even superior to, products of a similar purpose manufactured by other enterprises [6]. Taking into account the above and the fact that the food market of Ukraine and Europe is insufficiently provided with dietary products, the development of new products with specified functional characteristics based on consumer preferences is extremely necessary and relevant [7].

Thus, the object of research is the potential consumers of meat products. The subject of research is their consumer preferences.

The aim of research is design of new meat products for dietary purposes in accordance with consumer preferences.

\section{Methods of research}

The research method includes the use of quality management tools such as affinity diagram, tree diagram, and benchmarking technique [8-10]. The translation of consumer requirements in qualitative characteristics when designing a new meat product was determined using the QFD methodology [11].

The results of the columns «Level of improvement» are obtained by the formula [1]:

Level of improvement $=$

=target value: customer assessment. 
The weight of each consumer expectation is established by the formula [2]:

The weight of expectation $=$

=importance rating. degree of improvement .

The significance of the relationship is determined by the formula [3]:

The significance of the relationship=

$=$ the strength of the relationship $\times$

$\times$ significance, $\%$

Digital estimates of the significance of the strength of the relationships, each technical characteristic are given in the squares of the matrix of connections, «Quality houses», shown in Table 1.

Table 1

Digital estimates of the strength of relationships

\begin{tabular}{|c|c|c|}
\hline Symbol & 5trength of relationships & Weighting factor \\
\hline$\bigcirc$ & strong & 9 \\
\hline$\bigcirc$ & average & 3 \\
\hline$\triangle$ & weak & 1 \\
\hline
\end{tabular}

Digital estimates of the significance of the strength of the relationships of each technical characteristic of a new meat product, which are given in the squares of the relationship matrix, are calculated by the formula (3).

\section{Research results and discussion}

The creation of a high-quality meat product must begin with conducting market research to identify consumer motivations and preferences. The survey involved 210 people who are almost healthy and 390 who have certain diseases, namely: 109 people with iodine-deficient conditions, 154 people with celiac disease, 127 people with type 2 diabetes.

Consumer requirements for product quality were specified (unfolded) in stages, from the determination of the need to bring the product to the market and ending with quality control methods.

When developing the questionnaire, the Noriaki Kano method was used (Fig. 1), according to which the characteristics of the goods should satisfy the type of needs, which are divided into expected, desired and interesting. «Expected» or «binding» people take for granted requirements. Fulfilling the requirements of consumers regarding the required characteristics almost does not increase the consumer value of the product, but failure to do so drastically reduces consumer preferences. The «quantitative» customer satisfaction (that is, the conscious consumer value) is growing as the corresponding indicator is quantitatively improved. «Exciting» or «surprise» are bonus requirements.

The survey results, expressed in the «consumer language», were systematized and processed. The research results of consumer requirements regarding the development of a new meat product for dietary use are shown in Fig. 2.

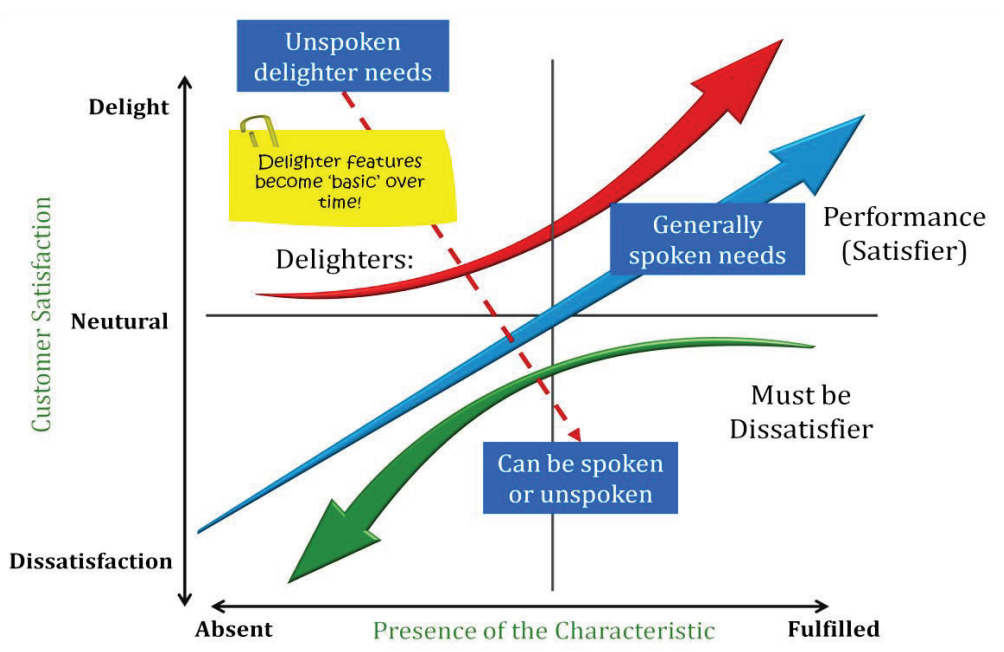

Fig. 1. Noriaki Kano quality model $[9,12]$

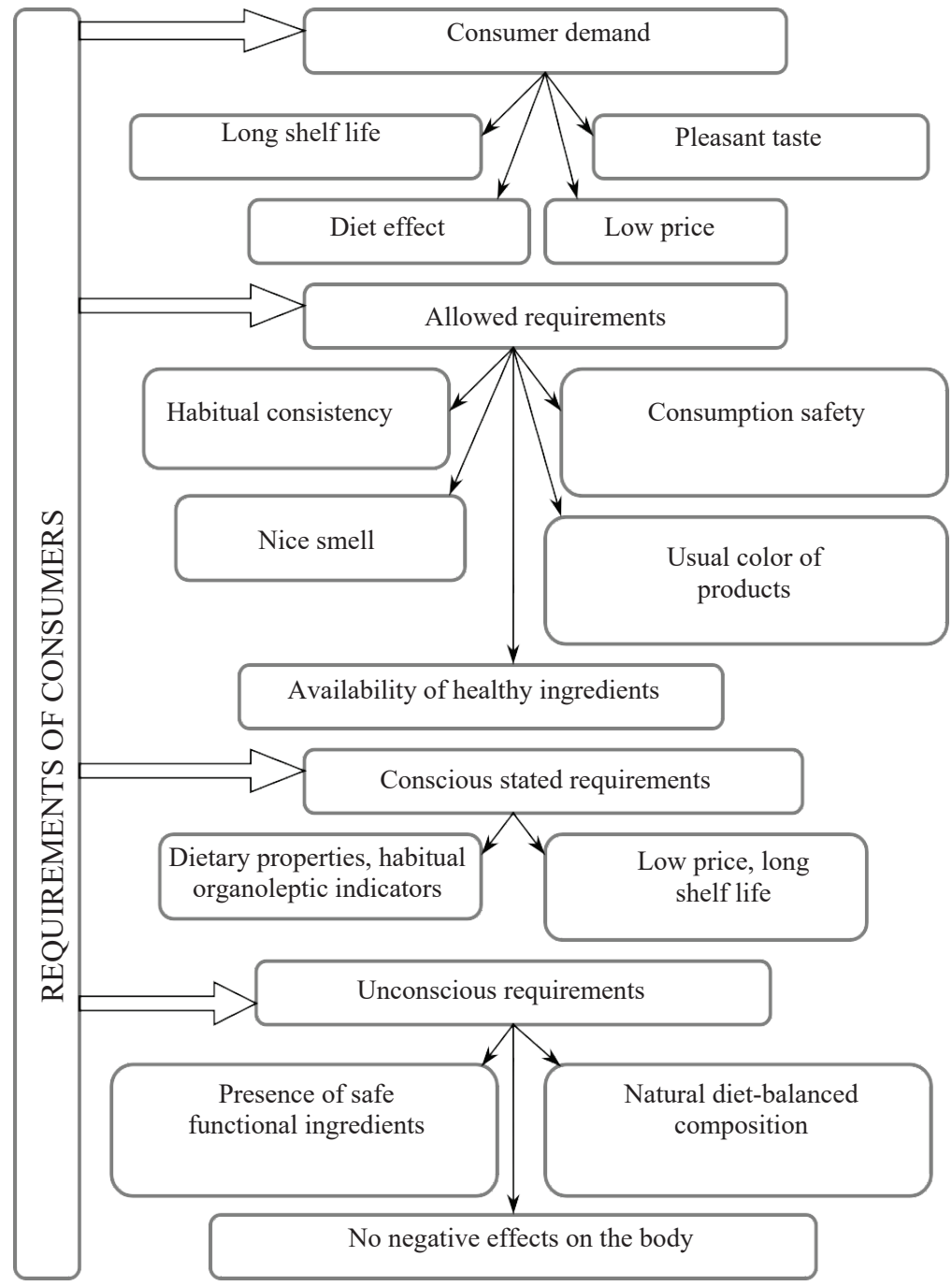

Fig. 2. Consumer requirements for the development of a new meat product 
Requirements are distributed on popular consumer requirements and requirements, admit, awareness of the statement of demand, unconscious requirements.

It is established that the consumer, among the demanded consumer requirements, wants to see a meat product with a long shelf life, pleasant taste, health-improving effect at a low price. Among the requirements, the consumer can assume that there are organoleptic indicators familiar to meat products, namely: familiar consistency and color, pleasant taste, the presence of useful ingredients that are safe for the human body.

Analyzing the survey data, it is found that the conscious consumer requirements for a new meat product for dietary purposes include dietary properties and habitual organoleptic characteristics, a long shelf life and the low price of the finished product. Unconscious of the requirements, this is a natural composition, balanced depending on the dietary purpose, the presence of safe functional ingredients and the absence of negative effects on the body when consumed. Consumer requirements are always contradictory and it is impossible to create products that would meet all consumer requirements, so it is necessary to know which requirements must be met, and which can be neglected to a certain extent [12].

In this regard, the requirements in Fig. 2 were prioritized. To do this, a repeated appeal was made to consumers (who have certain diseases), weight coefficients for individuals were established, namely, iodine deficiency conditions, type 2 diabetes and celiac disease are affected. In order to determine the comparative value of meat products designed with products that are already on the market, namely cooked smoked sausage «Delicatesna» of the trademark «Saltivsky meat processing plant» (Kharkiv, Ukraine), the benchmarking method are used. Comparison of competing meat products was conducted by the degree of satisfaction of consumer needs with a set of product characteristics.

The data of consumer surveys, which were transferred to a five-point scale, are given in Table 2 .

As can be seen from the Table 2, the transformation of consumer requirements into technical characteristics shows that the design of a new meat product should be based on the quality and quantitative content of raw materials. The chemical composition of the product, the mass fraction of protein, starch, the content of sodium chloride, the content of dietary supplements and their effect on the body depend on this. And also on the type and amount of additives and the presence of the preventive properties of the finished product. The requirements for safety indicators and energy value of the finished product have a direct impact. Based on the study of normative and technical documentation, the technical characteristics of cooked smoked sausages are determined, associated with the wishes and expectations of consumers. Namely: mass fraction of protein, mass fraction of starch, mass fraction of salt, mass fraction of moisture, energy value, content of wheat flour in the formulation, safety indicators, shelf life, cost.

To identify and establish the strength of the relationship between consumer requirements and technical characteristics, a matrix of links is compiled in the central «room» of the «Quality House», shown in Fig. 3.

An empty cell in the matrix indicates the absence of links between consumer expectations and product spe- cifications. If there is a relationship, then a symbol is entered into the cell to determine how strong the relationship is. In addition, for each characteristic, a criterion is calculated that takes into account the value of the strength of the relationships of a particular characteristic and the priority of requirements set by consumers. The strength of the relationship between the technical parameters is reflected in the elements of the triangular matrix, which represents the «roof of the house.» Roof cells are filled with information about how and which technical characteristic correlated with another. Since some technical characteristics are interconnected, it is not technically possible to mix variables in different directions correlated. Therefore, in each cell of the roof one of the following signs is put: either an empty cell, or $\bigcirc$, or $\mathrm{O}$, or $\Delta$. Thus, an exhaustive picture of dependencies is obtained.

Table 2

Comparison of competing meat products by the degree of satisfaction of consumer needs with a set of characteristics in the product

\begin{tabular}{|c|c|c|c|c|c|c|c|c|c|c|c|c|}
\hline $\begin{array}{l}\text { Consumer } \\
\text { requirements }\end{array}$ & 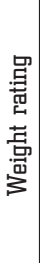 & & & 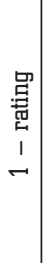 & $\begin{array}{c}\text { 邑 } \\
\text { 萝 } \\
1 \\
\sim \\
\sim\end{array}$ & $\begin{array}{c}\text { 邑 } \\
\text { 蒠 } \\
1 \\
\text { D }\end{array}$ & 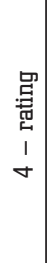 & $\begin{array}{c}\text { 罸 } \\
\text { 营 } \\
1 \\
1 \\
\text { ப }\end{array}$ & $\begin{array}{c}\text { 怘 } \\
\text { 品 } \\
\text { 㤩 } \\
\text { 急 } \\
\text { 总 }\end{array}$ & 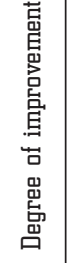 & 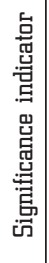 & 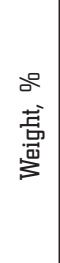 \\
\hline Pleasant taste & 5 & & & - & - & - & $1 / 2$ & - & 5 & 1 & 5 & 11 \\
\hline Nice view & 4 & & & - & - & - & $1 / 2$ & - & 5 & 1.25 & 5 & 11 \\
\hline $\begin{array}{l}\text { High nutritional } \\
\text { value }\end{array}$ & 5 & & & - & - & 2 & 1 & - & 5 & 1 & 5 & 11 \\
\hline $\begin{array}{l}\text { Functional } \\
\text { ingredient } \\
\text { content }\end{array}$ & 5 & & & - & - & 2 & 1 & - & 5 & 1 & 5 & 11 \\
\hline $\begin{array}{l}\text { Low calorie } \\
\text { content }\end{array}$ & 4 & & & - & - & - & $1 / 2$ & - & 4 & 1 & 4 & 8.6 \\
\hline Diet effect & 5 & & & - & - & 2 & & 1 & 5 & 1 & 5 & 11 \\
\hline Low price & 5 & & & - & - & - & 1 & 2 & 5 & 1 & 5 & 11 \\
\hline $\begin{array}{l}\text { Natural } \\
\text { composition }\end{array}$ & 5 & & & - & - & - & 2 & 1 & 5 & 1 & 5 & 11 \\
\hline Utility & 4 & : & & - & - & - & $1 / 2$ & - & 4 & 1 & 4 & 8.6 \\
\hline Long shelf life & 4 & & & - & - & - & $1 / 2$ & - & 4 & 1 & 4 & 8.6 \\
\hline Total score & - & - & - & - & - & - & - & - & - & - & 47 & 100 \\
\hline Priority, \% & - & - & - & - & - & - & - & - & - & - & & tal \\
\hline
\end{tabular}

Note: 1 - boiled-smoked sausage, which are designed; 2 - cooked smoked sausage "Delicatesna» of the trademark "Saltivsky meat processing plant» (Kharkiv, Ukraine) 


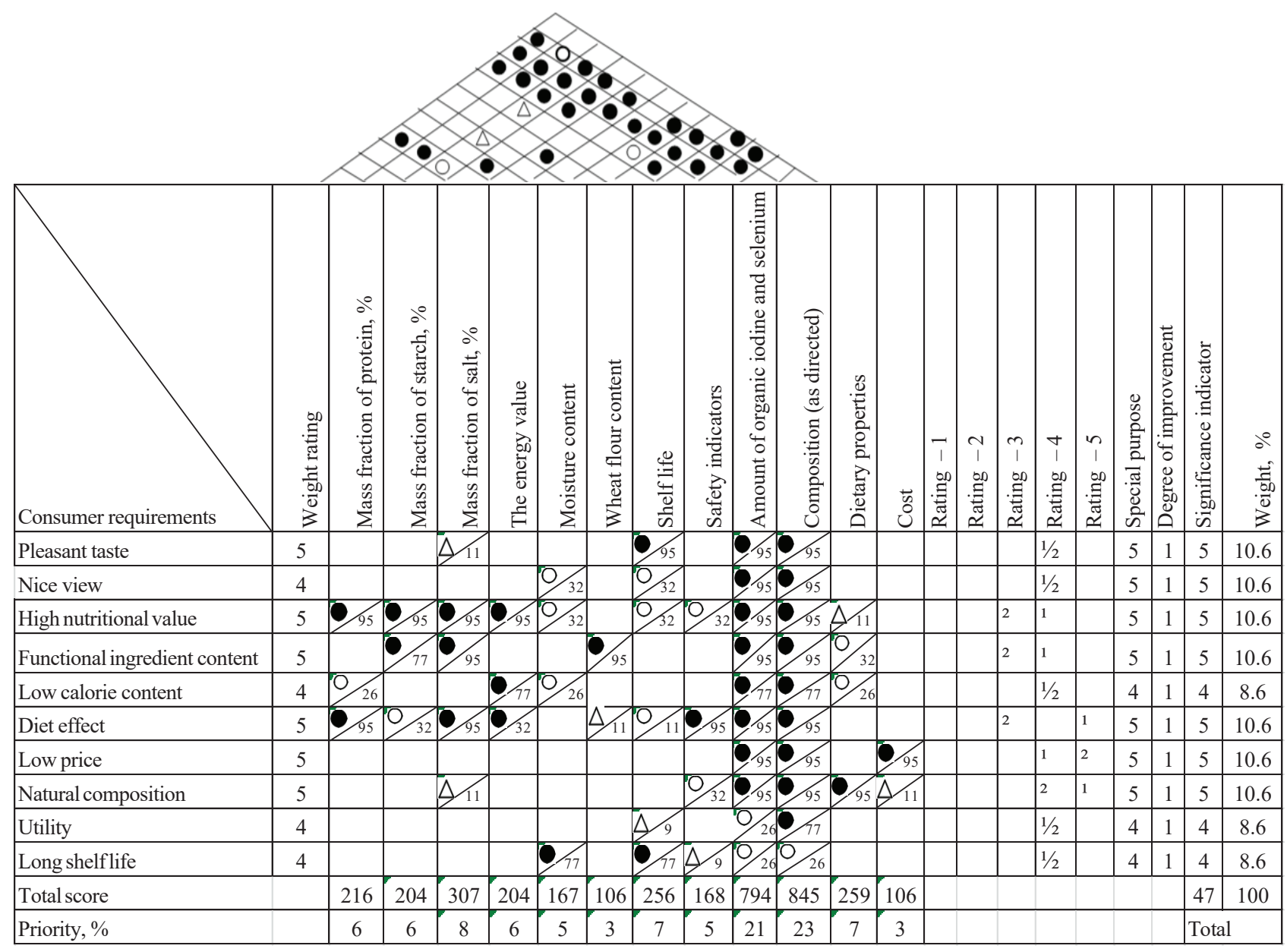

Fig. 3. "Quality House» for designing a new meat product for diet purposes

Summarizing the data on the strength of the relationship between the technical characteristics of cooked smoked sausages and the requirements of consumers, taking into account the importance of the latter, the optimization of the new product is prioritized and the «basement» of the Quality House is filled. As can be seen from Fig. 3, first of all, when developing new meat products taking into account consumer requirements, considerable attention should be paid to the use of raw materials, natural enriching additives, and will contribute to a safe product with a long shelf life, and most importantly, dietary purposes.

\section{Conclusions}

Using the methodology of deploying the quality function when designing a new meat product makes it possible to establish the needs of consumers for this product, identify the most important and promising ones, and convert their wishes into detailed technical specifications.

Designing a new meat product, taking into account the obtained results, will contribute to the production of competitive products, which in terms of their consumer properties will satisfy a certain contingent of consumers. It is found that when designing meat products for patients with celiac disease, wheat flour should be completely excluded from the recipes, replacing it with gluten-free types of flour - soybean, chickpea, which will enrich the meat products with essential amino acids. This replacement is also advisable for people suffering from type 2 diabetes, the amount of easily digestible carbohydrates should be limited in all forms of diabetes. As for the consumer preferences of people with iodine-deficient conditions, representatives of this segment want to consume meat products that are carriers of organic forms of iodine and selenium and a low content of table salt in products.

Application of the QFD methodology will minimize the correction of the quality of the meat product after it appears on the market and ensure high value and at the same time relatively low cost of the product by minimizing the cost of correcting inconsistencies. The prospect of further research is the scientific and practical substantiation of the recipes for new cooked smoked sausages for dietary purposes, taking into account the requirements of consumers.

\section{References}

1. Mardar, M. R., Kordzaia, N. R. (2013). Medical and biological estimation of bread made from a whole wheat grain with inclusion of root crops. Eastern-European Journal of Enterprise Technologies, 4 (10 (64)), 34-39. Available at: http://journals. uran.ua/eejet/article/view/16311

2. Matison, V. A., Kantere, V. M. (2012). Kliento-orientirovannoe konstruirovanie produktov pitaniia. Pischevaia promyshlennost, 2, 8-11.

3. Pro skhvalennia proektu Kontseptsii Derzhavnoi naukovo-tekhnichnoi prohramy «Biofortyfikatsiia ta funktsionalni produkty na osnovi roslynnoi syrovyny na 2012-2016 roky» (2011). Postanova 
NAN Ukrainy No. 189. 08.06.2011. Available at: https://zakon. rada.gov.ua/rada/show/v0189550-11?lang=uk

4. Pro skhvalennia Kontseptsii Zahalnoderzhavnoi prohramy «Zdorovia 2020: ukrainskyi vymir» (2011). Rozporiadzhennia Kabinetu Ministriv Ukrainy No. 1164-r. 31.10.2011. Available at: https:// www.kmu.gov.ua/npas/244717787

5. Tsymbalysta, N. V., Davydenko, N. V. (2008). Stan faktychnoho kharchuvannia naselennia ta alimentarne obumovlena zakhvoriuvanist. Problemy kharchuvannia, 1-2, 32-35.

6. Matison, V. A., Demidova, N. A. (2012). Primenenie metoda razvertyvaniia funkcii kachestva dlia konstruirovaniia produkta v pischevoi promyshlennosti. Pischevaia promyshlennost, 4, 44-45.

7. Doronin, A. F., Ipatova, L. G., Kochetkova, A. A. et. al. (2009) Funkcionalnye pischevye produkty. Vvedenie v tekhnologiiu. Moscow: DeLi print, 288

8. Akao, Y. (1990). Quality Function Deployment (QFD). In tegrating customer requirements into product design. Portland: Productivity Press, 369.

9. Misuno, S., Akao, Y. (1994). QFD. The customer-driven approach to quality planning and deployment. Tokyo: Asian Productivity Organization, 365.

10. Mardar, M. R. (2013). Application of the method of quality functional deployment when developing a new extruded product. Meridian ingineresc, 2, 30-33.
11. Suvorova, L. A., Cvirov, R. P. (2005). Primenenie metodologii QFD i statisticheskikh metodov v upravlenii kachestvom produkcii na promyshlennom predpriiatii. Kachestvo, innovacii, obrazovanie, 2, 72-78.

12. Yegorov, B. V., Mardar, M. R. (2012). Development of production principles for functional foods. Proceedings of 6th Central European Congress on Food. Novi Sad: Institute of Food Technology, 319-323.

Biletska Yana, PhD, Department of International E-commerce and Hotel and Restaurant Business, V. N. Karazin Kharkiv National University, Ukraine, e-mail: ya.belecka@karazin.ua, ORCID: http:// orcid.org/0000-0001-8060-6579

Bilovska Olha, PhD, Department of International E-commerce and Hotel and Restaurant Business, V. N. Karazin Kharkiv National University, Ukraine, e-mail: o.bilovska@karazin.ua, ORCID: http:// orcid.org/0000-0002-2808-5275

Zaitseva Anna, PhD, Department of International Economic Relations named after Arthur Golikov, V. N. Karazin Kharkiv National University, Ukraine, e-mail: glazkova@karazin.ua, ORCID: http:// orcid.org/0000-0003-0818-7853 